\title{
GH mutant (R77C) in a pedigree presenting with the delay of growth and pubertal development: structural analysis of the mutant and evaluation of the biological activity
}

\author{
Vibor Petkovic $^{1}$, Mario Thevis ${ }^{2}$, Didier Lochmatter ${ }^{1}$, Amélie Besson ${ }^{1}$, Andrée Eblé ${ }^{1}$, Christa E Flück ${ }^{1}$ and \\ Primus E Mullis ${ }^{1,3}$ \\ ${ }^{1}$ University Children's Hospital, Pediatric Endocrinology, Diabetology and Metabolism, Inselspital, CH-3010 Bern, Switzerland, ${ }^{2}$ Center for Preventive \\ Doping Research-Institute of Biochemistry, German Sport University Cologne, 50933 Cologne, Germany and ${ }^{3}$ National Institute for Medical Research, \\ Mill Hill, London NW7 1AA, UK \\ (Correspondence should be addressed to P E Mullis; Email: primus.mullis@insel.ch)
}

\begin{abstract}
A heterozygous missense mutation in the $G H-1$ gene converting codon 77 from arginine $(\mathrm{R})$ to cysteine $(\mathrm{C})$, which was previously reported to have some GH antagonistic effect, was identified in a Syrian family. The index patient, a boy, was referred for assessment of his short stature ( -2.5 SDS $)$ at the age of 6 years. His mother and grandfather were also carrying the same mutation, but did not differ in adult height from the other unaffected family members. Hormonal examination in all affected subjects revealed increased basal GH, low IGF-I concentrations, and subnormal IGF-I response in generation test leading to the diagnosis of partial GH insensitivity. However, GH receptor gene (GHR) sequencing demonstrated no abnormalities. As other family members carrying the GH-R77C form showed similar alterations at the hormonal level, but presented with normal final height, no GH therapy was given to the boy, but he was followed through his pubertal development which was delayed. At the age of 20 years he reached his final height, which was normal within his parental target height. Functional characterization of the GH-R77C, assessed through activation of Jak2/Stat 5 pathway, revealed no differences in the bioactivity between wild-type-GH (wt-GH) and GH-R77C. Detailed structural analysis indicated that the structure of GH-R77C, in terms of disulfide bond formation, is almost identical to that of the wt-GH despite the introduced mutation (Cys77). Previous studies from our group demonstrated a reduced capability of GH-R 77C to induce GHR/GH-binding protein $(G H B P)$ gene transcription rate when compared with wt-GH. Therefore, reduced GHR/GHBP expression might well be the possible cause for the partial GH insensitivity found in our patients. In addition, this group of patients deserve further attention because they could represent a distinct clinical entity underlining that an altered GH peptide may also have a direct impact on GHR/GHBP gene expression causing partial GH insensitivity. This might be responsible for the delay of growth and pubertal development. Finally, we clearly demonstrate that GH-R 77C is not invariably associated with short stature, but that great care needs to be taken in ascribing growth failure to various heterozygous mutations affecting the GH-IGF axis and that careful functional studies are mandatory.
\end{abstract}

European Journal of Endocrinology 157 S67-S74

\section{Introduction}

Growth disorders and short stature are a common clinical problem. Although most cases are sporadic and result from environmental insults or developmental abnormalities, there are estimates of the frequency of genetic causes, including growth hormone deficiency (GHD), GH insensitivity (Laron syndrome), and/or reduced bioactivity of GH (Kowarski syndrome) ranging from 1 in 4000 to 1 in 10000 live births (1-4).

This paper was presented at the Ipsen symposium, 'The evolving biology of growth and metabolism', Lisbon, Portugal, 16-18 March 2007. Ipsen has supported the publication of these proceedings.
$\mathrm{GH}$ plays a major role in postnatal growth. The gene is mainly expressed in the pituitary gland as a protein, which is characterized by an arrangement of four antiparallel $\alpha$-helices separated by connecting loops (5). GH receptor (GHR) exists as an inactive dimer at the cell surface, and its activation involves a hormone-induced relative rotation of subunits, bringing the Jak2 kinases in close proximity $(6,7)$. The kinases phosphorylate the receptor, crossphosphorylate themselves, and start signal transduction by phosphorylating downstream signal transduction molecules, including signal transducer and activator of transcription Stat5 (8, 9). Activated Stat 5 is translocated to the nucleus where it transactivates a series of GH-responsive genes (10). 
Takahashi et al. described severe short stature in a boy due to a single mutation converting codon 77 from arginine to cysteine (GH-R77C) $(11,12)$. However, the patient's father was of normal stature even though he was carrying the same heterozygous mutation. Recombinant GH therapy used in this study was not sufficiently effective in stimulating somatic growth of this patient. Structural analysis of GH-R77C mutant expressed and purified from Escherichia coli performed by Chihara et al. (12) indicated the presence of a disulfide bond between cysteine 77 and 53 or 165 , presumably causing a conformational change of GH-R77C. Deladoey et al. studied the effect of GH-R77C on GHR/GH-binding protein (GHBP) gene transcription and clearly showed, when compared with wild-type-GH ( $w t-\mathrm{GH}$ ), a reduced capability of GH-R77C in stimulation of GHR/GHBP gene transcription (13). Our group has recently reported the detailed functional characterization of GH-R 77C when compared with wt-GH describing very similar affinity of wt-GH and GH-R 77C for the GHR and GHBP and almost identically regulated secretion of both peptides in AtT-20 cells (14). These data were complemented by cell proliferation results showing that GH-R 77C does not exert any effect different from that of the wt-GH in terms of cell viability and/or proliferation in AtT-20 cells.

Here, we report a pedigree over three generations of a Syrian family where all affected subjects carry the same heterozygous GH-R77C mutation. Our patient presented with short stature ( -2.5 SDS) at the age of 6 years caused by partial GH insensitivity. All other affected family members carrying the GH-R77C allele reached a normal final height within the parental target height after a reported delay of growth and pubertal development in childhood. In addition, we focus on detailed structural analysis of this GH-R77C mutant form expressed and purified from mammalian cells, comparing it with wt-GH.

\section{Subject and methods}

\section{Patient and family}

The patient, of Syrian (Kurd) ancestry, immigrated to Switzerland at the age of 6 years. He presented at this time with short stature $(-2.5$ S.D. score for age and sex) (15). The pedigree of his non-consanguineous family is presented in Fig. 1A. Standard auxological assessment was performed (16). He had no evidence of an organic disease, psychological deprivation, or any eating disorder, and renal and hepatic functions were normal. A standard pharmacological stimulation test (insulin-induced hypoglycemia) was performed (17). Auxological and laboratory data are presented in Table 1. Genetic analysis revealed a normal GHR gene (all the exons, exon/intron boundaries were sequenced), but a familial $\mathrm{R} 77 \mathrm{C}$ heterozygous mutation of the GH-1 gene was found. By analyzing the hereditary distribution of the GH-1 gene defect throughout the pedigree, an autosomal dominant 'growth' disorder could be suggested. However, as the other genetically
A

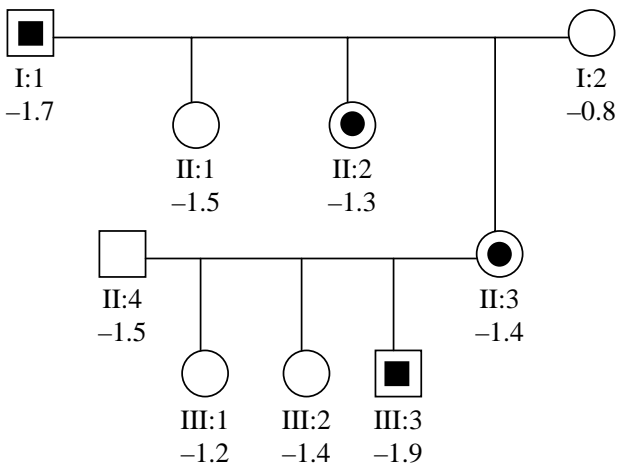

B

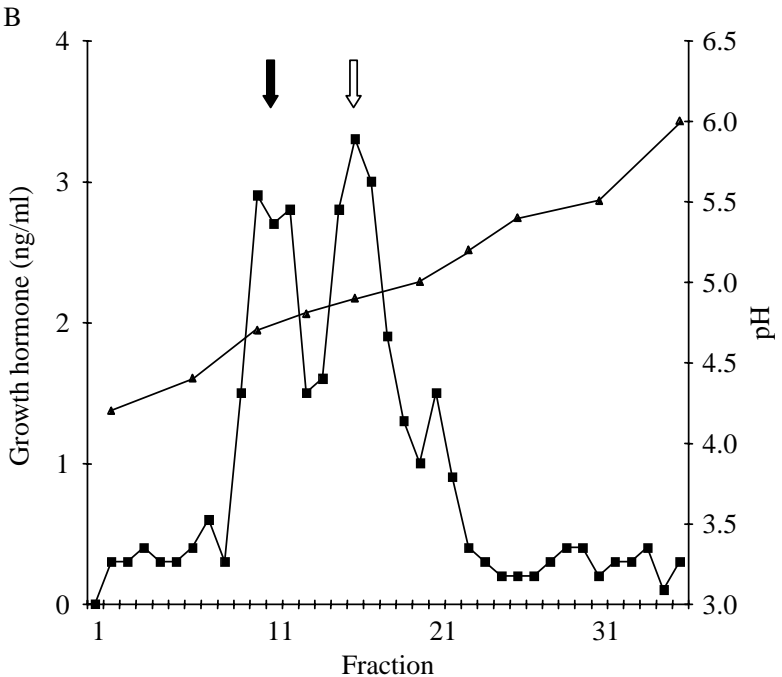

Figure 1 (A) A three-generation pedigree of the patient's family is shown, with affected individuals indicated in open symbols containing smaller solid symbols. The adult height S.D. score is reported. DNA sequencing revealed that the affected subjects presented heterozygosity for the R77C transition mutation of the $\mathrm{GH}$-1 gene. The R77C mutations was screened for, but was not detected, in 100 alleles from unrelated normal individuals. (B) Isoelectric focusing of growth hormone in serum from the patient III:3. The serum fractions were pooled separately and assayed for growth hormone immunoreactivity. The $\mathrm{pH}$ gradient formed during isoelectric focusing is indicated. The peaks for wild-type and mutant growth hormone are indicated by the open and solid arrows respectively.

affected family members were of normal adult stature and, at follow-up of this affected boy, the height velocity remained in the normal range for his family, no GH treatment was initiated; but he was followed through puberty, which was delayed allowing the clinical diagnosis of delay of growth and pubertal development at that time. Finally, at the age of 20 years he reached the final height of $167.2 \mathrm{~cm}(-1.9$ S.D.s $)$ in good health and his school performance was normal. Informed written consent was obtained from the patient, subjects examined, and from the parents of the patients enrolled in this study.

\section{Isoelectric focusing}

Isoelectric focusing was performed as described previously (18). Serum samples (200-300 $\mu \mathrm{l})$ were electrofocused in 


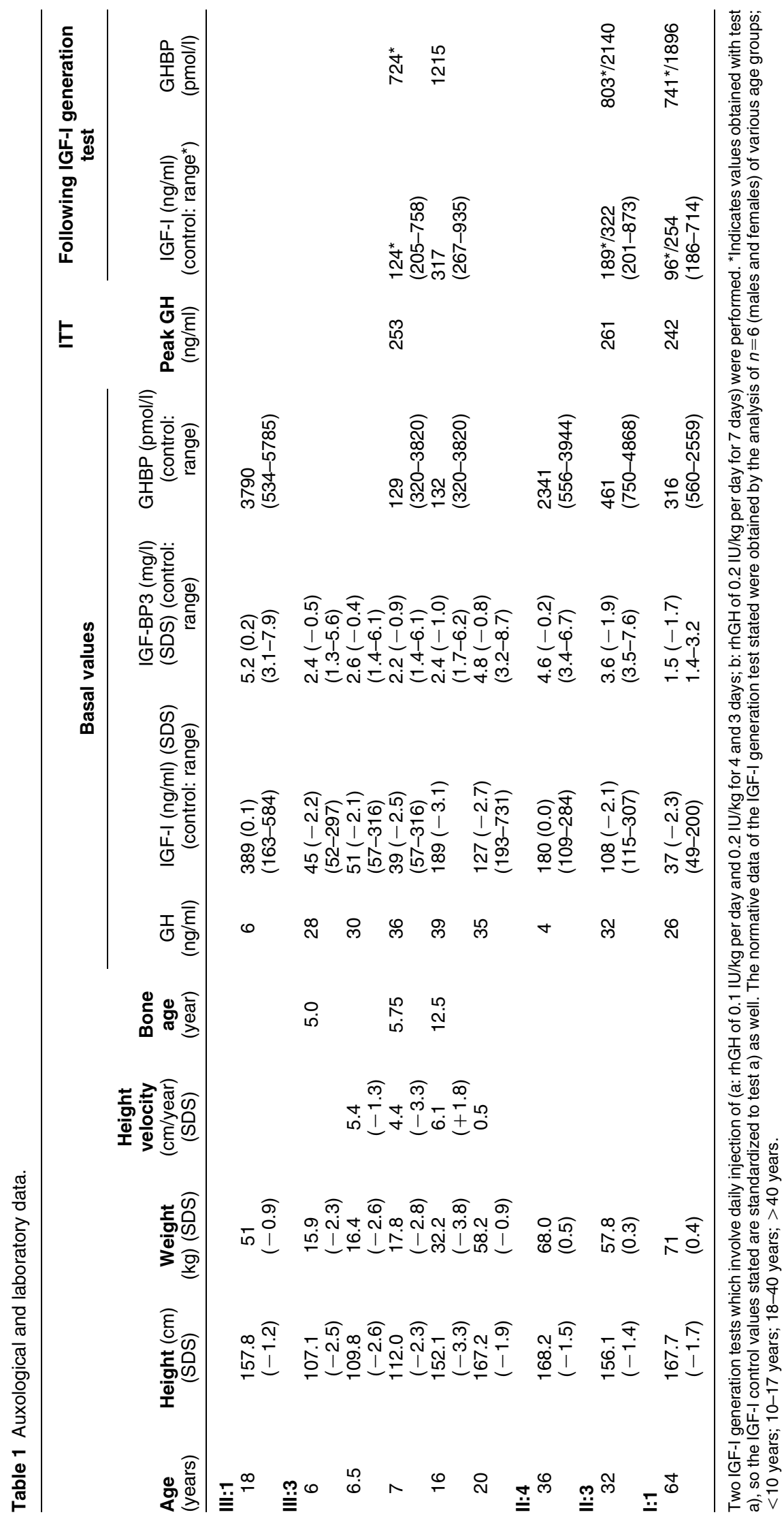


a buffer containing 1\% hydroxypropyl methylcellulose and $4 \%$ ampholine (pH gradient, 3.5-8.0) at $200 \mathrm{~V}$ for $12 \mathrm{~h}$ and then at $500 \mathrm{~V}$ for $12 \mathrm{~h}$. The fractions were collected and assayed for immunoreactive GH. Pooled serum samples from seven normal subjects were used as the control.

\section{Cell culture and treatment}

Chinese hamster ovary (CHO-K1) cells were a gift from Prof. U Wiesmann (Inselspital, Bern, Switzerland) and were cultured in Ham's F12 medium (Biochrom AG Seromed, Berlin, Germany) supplemented with $10 \%$ fetal calf serum, $100 \mathrm{U} / \mathrm{l}$ penicillin/streptomycin (Biochrom AG), and $2 \mathrm{mM}$ L-glutamine (Gibco-BRL, Life Technologies).

Human embryonic kidney 293 cells stably expressing human GHR (293GHR) were grown in Dublecco's modified Eagle's medium-nutrient mix F12 (Gibco), supplemented with $10 \% \mathrm{FCS}, 100 \mathrm{U} / \mathrm{l}$ penicillin/streptomycin, $2 \mathrm{mM}$ L-glutamine, and $400 \mu \mathrm{g} / \mathrm{ml}$ Geneticin G418 (Promega Corp).

\section{Expression vectors}

Wt-GH was cloned in pcDNA3.1 $(-) / \mathrm{Neo}$ (Invitrogen) vector as described (19), and GH mutant studied (GH$\mathrm{R} 77 \mathrm{C}$ ) was generated using site-directed mutagenesis (14).

\section{Production of GH peptides}

In order to produce $\mathrm{GH}$ variants, wt-GH and GH-R77C, stable clones were generated in CHO-K1 cells by transfection with FuGene 6 (Roche Diagnostics AG).

The concentration of the $\mathrm{GH}$ produced by the $\mathrm{CHO}$ cells during 3 days in Ham's F12 media (without FCS) was measured by the DSL-GH ELISA Kit (DSL, Webster, TX, USA).To confirm that the mutation R77C does not affect the affinity of the antibody used in the DSL-ELISA, additionally two different $\mathrm{GH}$ assays were performed on two samples of CHO supernatant and the results were compared (20).

\section{Hormonal measurement}

The serum GH, insulin-like growth factor-I (IGF-I), IGFbinding protein-3 (IGF-BP3), and GHBP were measured as described previously (14).

\section{Luciferase reporter gene assay of Stat5 activation}

293GHR cells were used to assay Stat5 activation as described previously $(21,22)$. Briefly, cells were transfected with a Stat5-responsive luciferase reporter gene construct $(23,24)$ and treated with either recombinant human $\mathrm{GH}$ (rhGH), wt-GH or GH-R77C (all at $50 \mathrm{ng} / \mathrm{ml}$ concentrations) for $6 \mathrm{~h}$. Luciferase expression was then measured with a luminometer (Mediators PhL, Aureon Biosystems, Vienna, Austria).
Recombinant human GHBP (rhGHBP) was a gift from Terri Smith, Genetech Inc. (San Francisco, CA, USA).

\section{Structure of GH-R77C}

In order to compare and study the chemical structure of GH-R77C, wt-GH was extracted and purified from somatrope cell material (Anti-Doping Laboratory, Cologne, Germany), and GH-R 77C from the cell culture supernatant as described. The extracts were subjected to solid-phase extraction using pre-packed Oasis HLB C-18 cartridges (Waters, Milford, MA, USA) and subsequently hydrolyzed using sequencing grade porcine trypsin (Promega). The samples were applied to a capillary liquid chromatograph (Agilent Technologies, Waldbronn, Germany) interfaced to an LTQ-Orbitrap mass analyzer (Thermo Electron, Bremen, Germany). After gradient elution, full scan mass spectrometry was performed using the LTQ-Orbitrap at a resolution of 30000 and product ion spectra were recorded employing the LTQ linear ion trap only. In addition, GH-R77C was derivatized using acrylamide under non-reducing conditions and subsequently trypsinized, and additional alkylation studies were performed and the disulfide bonds were structurally analyzed.

\section{Results}

\section{Clinical diagnosis and follow-up}

As this family entered Switzerland as refugees, no exact data on birth weight and length are available. However, the parents reported no abnormalities, as was his psychomotor development. As the clinical phenotype as well as the laboratory finding of rather high basal GH concentration, high peak GH level after provocation test, and low basal IGF-I concentration in this 7-year-old boy suggested partial GH insensitivity (Table 1), the GHR gene was sequenced and an IGF-I generation test was performed (25). This detailed assessment, however, presented a normal sequence of the GHR-gene (exons, exon/intron boundaries) but only a subnormal IGF-I $(124 \mathrm{ng} / \mathrm{ml})$ response after an IGF-I generation test (daily injection of $\mathrm{rhGH}$ of $0.1 \mathrm{IU} / \mathrm{kg}$ per day and $0.2 \mathrm{IU} / \mathrm{kg}$ for 4 and 3 days respectively), and therefore the possibility of a functionally altered $\mathrm{GH}$ affecting GHR binding/signaling was hypothesized. The sequencing of the GH-1 gene revealed a heterozygous $\mathrm{R} 7 \mathrm{C}$ transition mutation, which was previously reported to have some GH antagonistic effect $(19,20)$. Therefore, the whole family was clinically studied (his unaffected father and sister and affected mother as well as grandfather) in more detail (Fig. 1A, Table 1). Importantly, isoelectric focusing revealed the presence of an abnormal GH peak in addition to a normal peak (Fig. 1B: III:3) in the boy. In this family, the presence of GH-R77C correlated with the delay in growth and pubertal development (mother menarche at the age of 18 years) but did not present a clear phenotype in terms of 
short stature/final height. In contrast, at the hormonal level, a slight GH insensitivity was hypothesized and therefore further studies were performed in order to define in more detail the effect of GH-R77C at the cellular level. In addition, at the age of 16 years the IGF-I generation test was repeated in the boy. However, the dose of rhGH was increased to $0.2 \mathrm{IU} / \mathrm{kg}$ for 7 days. The IGF-I response was significantly increased from a subnormal value (189 ng/ $\mathrm{ml})$ to an accepted normal value $(317 \mathrm{ng} / \mathrm{ml}$; Table 1$)$. Importantly, under these circumstances GHBP increased as well (Table 1). Additionally, in affected subjects (II:3; $\mathrm{I}: 1)$ two IGF-I generations tests were performed (a: daily injection of $\mathrm{rhGH}$ of $0.1 \mathrm{IU} / \mathrm{kg}$ per day and $0.2 \mathrm{IU} / \mathrm{kg}$ for 4 and 3 days respectively; b: daily injection of rhGH of $0.2 \mathrm{IU} / \mathrm{kg}$ per day for 7 days), confirming the results obtained in III:3 (Table 1).

\section{Functional and structural characterization of GH-R 7 7C}

To investigate in more detail the bioactivity of GH-R77C, 293GHR cells stably expressing GHR were used. Furthermore, a Stat5-responsive luciferase reporter gene assay system $(21,22)$ performed in these cells, which requires all stages of the Jak $2 /$ Stat 5 signaling pathway to be functional, was used to assay and quantify signal transduction activity of GH-R77C.

As depicted in Fig. 2, the effects of rhGH, wt-GH, and GH-R77C (all at $50 \mathrm{ng} / \mathrm{ml}$ concentrations) on activation of the Jak $2 /$ Stat 5 pathway were compared and found not to be significantly different. Of note is that the western blots performed with the supernatant from CHO cells, containing either wt-GH or GH-R77C, confirmed that the sizes of both $\mathrm{GH}$ variants were the same at $22 \mathrm{kDa}$ (data not shown).

As the additional cysteine at position 77 may affect disulfide bond formation and, therefore, change the structural conformation, GH-R77C was expressed and purified from mammalian cells ( $\mathrm{CHO}$ cells) and the structural analysis of the mutant was performed and

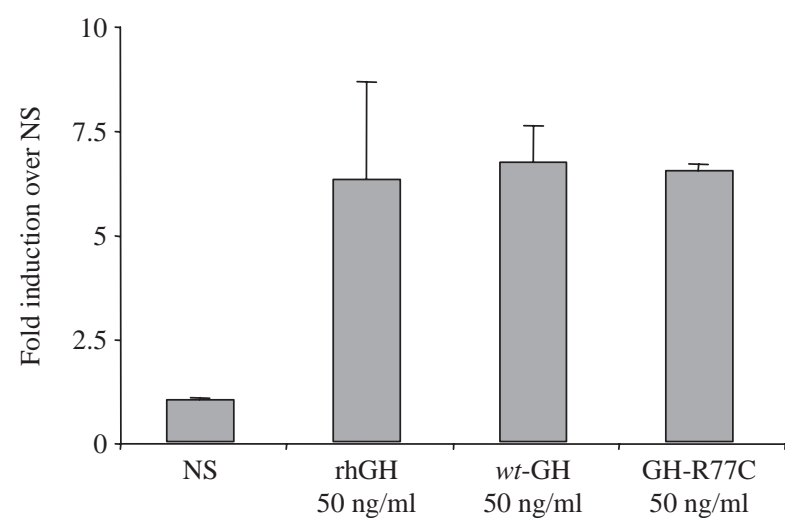

Figure 2 Jak2/Stat5 signaling capacity of $\mathrm{rhGH}$, wt-GH, and $\mathrm{GH}-\mathrm{R} 77 \mathrm{C}$. Results are expressed as a fold induction relative to the basic activity of non-stimulated cells and represent the means \pm S.D. of three independent experiments. NS, non-stimulated. compared with wt-GH. After the derivatization of the introduced cysteine residue $\left(\mathrm{C}^{*}\right)$ using acrylamide, the LC-ESI-MS/MS spectrum (Fig. 3A) of the triply charged molecule $(\mathrm{M}+3 \mathrm{H})^{3+}$ at $\mathrm{m} / \mathrm{z} 967$ of the peptide resulting from trypsinization of GH-R77C mutation confirmed the presence of R77C mutation.

Extracted ion chromatograms obtained from GH-R77C (Fig. 3B) by LC-ESI-high resolution/high accuracy mass spectrometry and ion trap tandem mass spectrometry illustrated the presence of a triply charged molecule (the inset in Fig. 3B) at $\mathrm{m} / \mathrm{z} 967.5444$ (apex) with an average molecular mass of $2898.6 \mathrm{kDa}$ (theor: 2898.4) and extracted ion traces of abundant product ions $\left(\mathrm{y}_{6}-\mathrm{y}_{8}\right)$ resulting from the target peptide after collision-induced dissociation. Extracted ion chromatograms obtained from wt-GH (Fig. 3C) illustrated the absence of a triply charged molecule at $\mathrm{m} / \mathrm{z}$ 967.5444 (retention time $29.2 \mathrm{~min}$ ) and, thus, the lack of the mutant peptide in Fig. 3B. The extracted ion traces of the target peptide after collision-induced dissociation also confirm no R/C substitution in wt-GH.

Moreover, GH-R 77C was derivatized using acrylamide under non-reducing conditions and subsequently trypsinized. The peptide comprising the modified position (Cys77) was found to be alkylated, indicating that the free sulfhydryl residue is not involved in other intramolecular disulfide bonds, although it has been reported that the alkylation of cysteines involved in disulfide bonds may occur to a very minor extent (26).

\section{Discussion}

A heterozygous missense mutation in the $\mathrm{GH}-1$ gene converting codon 77 from arginine $(\mathrm{R})$ to cysteine $(\mathrm{C})$ was identified in our patient. Apart from the affected patient, his mother and grandfather were also carrying the same mutation. However, they did not differ in terms of phenotype (final height) but in terms of laboratory values $(\mathrm{GH}$ insensitivity) from the other unaffected family members (Fig. 1A and Table 1). Isoelectric focusing confirmed the presence of both wt-GH and GH-R77C in the patient's serum (Fig. 1B). Our recently published data demonstrated very similar affinity of $w t-G H$ and GH-R 77C for the GHR and GHBP (14). Furthermore, comparing the association of either wt-GH or GH-R77C with different compartments within the secretory pathway, namely the endoplasmic reticulum, Golgi, and secretory vesicles clearly showed that both GH peptides pass through the very complex secretory machinery in an almost identical manner. Therefore, our clinical and experimental findings do not support the previously reported hypothesis that the presence of GH-R77C in the circulation correlates with the severe short stature $(11,12)$.

Further functional characterization of this mutant was pursued by bioassay. The efficiency of this assay focusing on the GHJak2/Stat 5 signaling pathway was assessed first by stimulation of the $293 \mathrm{GHR}$ cells with increasing 
A
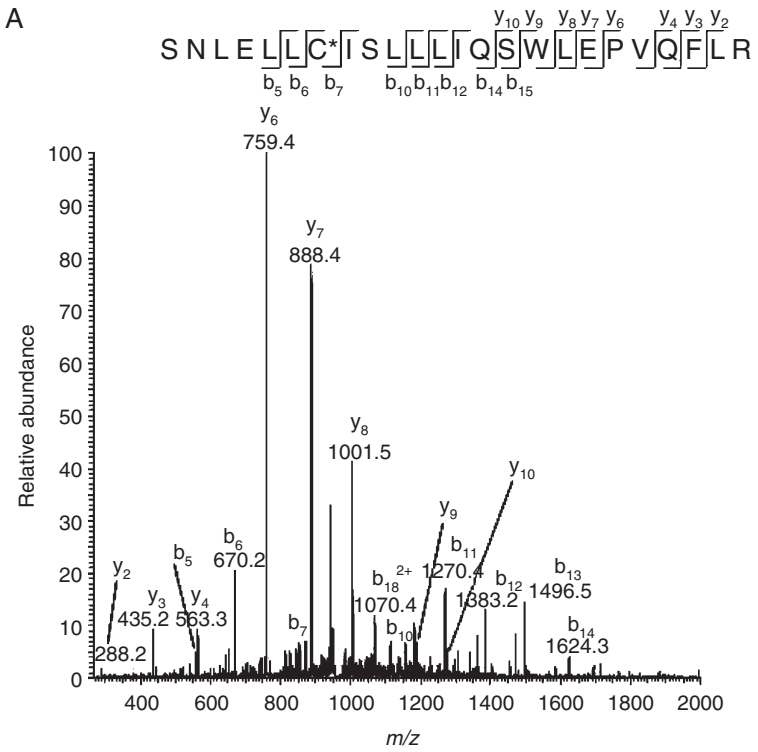

B

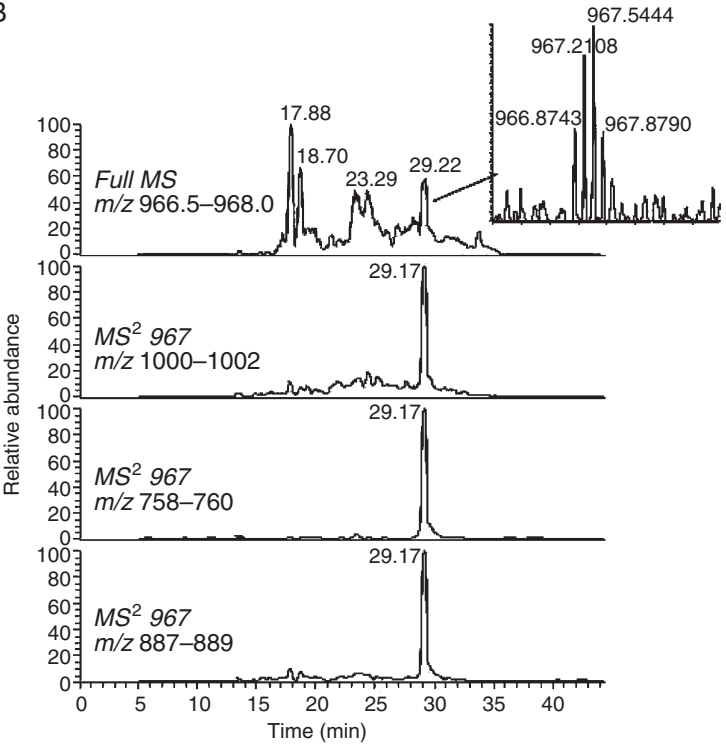

C

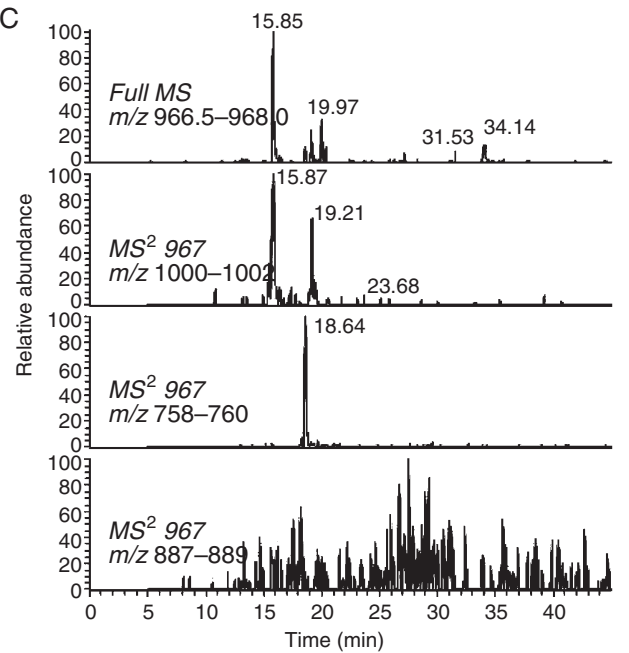

amounts of rhGH. Effectively, the production of firefly luciferase increased proportionally to the concentrations of rhGH added in the system (data not shown). Moreover, the activity of the $\mathrm{GH}-\mathrm{R} 77 \mathrm{C}$ produced by the $\mathrm{CHO}$ cells was comparable with that of the rhGH and $w t-G H$, all at the same concentration (Fig. 2).

In the study by Chihara et al. (12) in which the authors reported the aberrant formation of disulfide bonds between cysteine 77 and 53 or 165 , the GH-R77C was produced in E. coli, purified, and used for reversed HPLC. However, in this study there are no indications that after expression of $\mathrm{GH}$ peptides in bacteria the process of refolding, which assures the high yield of correctly folded proteins, excluding at the same time misfolded forms and multimers, was assessed. Moreover, protein disulfide isomerase family members, present in ER of eukaryotes but not in prokaryotes, are known to catalyze all of the reactions that are involved in native disulfide bond formation (oxidation) and cleavage or rearrangement (isomerization) of incorrect disulfide bonds $(27,28)$. Due to these facts and in order to perform detailed structural analysis, we decided to express and produce our GH-R77C peptide in a mammalian cell line ( $\mathrm{CHO}$ cells). Besides the mutated amino acid at codon 77 (arginine to cysteine), the structural analysis of GH-R77C was revealed to be similar to wt-GH. Partial reduction and alkylation of proteins containing disulfide bonds has been commonly employed for disulfide bridge mapping and characterization $(29,30)$. GH-R77C was found to be normally alkylated at the position Cys77, indicating that the free sulfhydryl residue is not involved in other intramolecular disulfide bonds, although it has been reported that the alkylation of cysteines involved in disulfide bonds may occur to a very minor extent (26). Hence, there is an indication that the structure of GH-R77C mutant, expressed and purified from mammalian cells, is very similar (if not identical) to that of the $w t-\mathrm{GH}$ despite the introduced mutation.

In a previous study reported by our group, Deladoey et al. analyzed the impact of the different GH mutants, including GH-R77C, on GHR/GHBP gene transcription in a human hepatoma cell line (HuH7 cells) (13). It was observed that the GHR transcription rate was significantly reduced by $\mathrm{GH}-\mathrm{R} 77 \mathrm{C}$ when compared with that of the wt-GH but still significantly higher than that of the genetically engineered GHR antagonist, pegvisomant. In addition, these data were confirmed by run-on experiments using cyclohexamide, the inhibitor of protein synthesis, which did not affect these changes,

Figure 3 (A) LC-ESI-MS/MS spectrum of the triply charged molecule $(\mathrm{M}+3 \mathrm{H})^{3+}$ at $\mathrm{m} / \mathrm{z} 967$ of the peptide resulting from trypsinization of GH-R77C mutation. Extracted ion chromatograms are obtained from GH-R77C (B) and wt-GH (C) by LC-ESI-high resolution/high accuracy mass spectrometry and ion trap tandem mass spectrometry illustrating the presence and absence of the mutant-specific peptide (retention time $29.2 \mathrm{~min}$ ) respectively. 
supporting the notion that the GHR/GHBP gene transcription was directly stimulated and depended, at least partially, on some pre-existing factors.

On the clinical and protein basis, GHBP was significantly decreased $(P<0.001)$ in the affected subjects compared with the normal controls. Further, as the GHR was sequenced and found to be normal, the reduced GHR/GHBP expression caused by the GH-R77C mutant might well be responsible for causing GH insensitivity. Additional functional studies focusing on the GHR are supporting this notion (14). However, this possible direct impact of GH-R77C at the GHR/GHBP level, also still unclear in its mechanism, is underlined by the normalization of IGF-I response when rhGH dose was increased from $0.1 \mathrm{IU} / \mathrm{kg}$ per day to $0.2 \mathrm{IU} / \mathrm{kg}$ during the period of 7 days as described previously (14).

It is well known that under normal physiological conditions, GHBP is bound to almost half of GH in human plasma $(31,32)$, acting as a reservoir of $\mathrm{GH}$ and thereby prolonging its half-life. GHBP is generated by proteolytic cleavage of GHR at the cell surface and modulation of GHR turnover/internalization might impact the level of GHR available for proteolysis. Therefore, one could hypothesize that the reduced GHR/GHBP gene transcription rate evoked by GH-R77C compared with the $w t-G H$ may lead to a reduced amount of GHR, which are going to be produced and exported at the cell surface. Consequently, that might affect the level of GHBP generated by proteolytic cleavage of GHR and might explain the low levels of GHBP found in our patient carrying GH-R77C mutation.

In conclusion, we report further details on a heterozygous missense mutation, $\mathrm{R} 77 \mathrm{C}$ in the $\mathrm{GH}$ molecule in a patient with growth retardation, and delayed pubertal development. No differences between $w t-\mathrm{GH}$ and $\mathrm{GH}-\mathrm{R} 77 \mathrm{C}$ were found by functional characterization of the GH-R 77C through GHR binding, activation of Jak $2 /$ Stat 5 pathway, and additional secretion studies together with cell proliferation when stably GHR transfected cells (293GHR) were used (14). In addition, the structural characterization of GH-R 77C mutant reported in this study revealed no structural differences when compared with wt-GH. On the other hand, reduced capability of GH-R77C to directly induce GHR/GHBP gene transcription rate could indirectly affect the levels of GHBP in the circulation of our patient. In addition, this group of patients deserve further attention because they could represent a distinct clinical entity underlining that an altered GH peptide may cause partial GH insensitivity through direct impact on GHR/ GHBP gene expression, leading to the delay of growth and pubertal development. Finally, GH-R77C is not invariably associated with short stature, although the serum IGF-I levels are low, the GH is elevated, and the GHBP levels are somewhat low, consistent with some degree of GH insensitivity, which is presumably compensated for by excess of $\mathrm{GH}$ production. Whether this is due to GHR transcription defects remains unclear.

\section{Acknowledgements}

We thank Dr Terri Smith from Genetech Inc. for generously providing us with rhGHBP. This work was supported by an SNF grant to P EM (3200B0-105853/1). Furthermore, we are very grateful to Ron G Rosenfeld, for his constructive comments and suggestions while performing the studies. In addition, thanks go to the European Society for Paediatric Endocrinology supporting P E M with its sabbatical leave programme; P E M currently works at the National Institute for Medical Research, at Mill Hill, London, UK.

\section{Disclosure}

This paper forms part of a European Journal of Endocrinology supplement, supported by Ipsen. The authors disclose: Vibor Petkovic, Mario Thevis, Didier Lochmatter, Amélie Besson, Andrée Eblé, Christa E Flück and Primus E Mullis have no relationship with Ipsen. This article was subject to rigorous peer review before acceptance and publication.

\section{References}

1 Vimpani GV, Vimpani AF, Lidgard GP, Cameron EHD \& Farquhar JW. Prevalence of severe growth hormone deficiency. BMJ 19772 427-430.

2 Lacey KA \& Parkin JM. Causes of short stature. Lancet 19741 $42-45$.

3 Rona RJ \& Tanner JM. Aetiology of idiopathic growth hormone deficiency in England and Wales. Archives of Disease in Childhood 197752 197-208.

4 Lindsay R, Harris D, Feldkamp M, Robertson J \& Rallison M. Utah Growth Study: growth standards and the prevalence of growth hormone deficiency. Journal of Pediatrics 1994125 29-35.

5 De Vos AM, Ultsch M \& Kossiakoff AA. Human growth hormone and extracellular domain of its receptor: crystal structure of the complex. Science 1992255 306-312.

6 Gent J, Van Den Eijnden M, Van Kerkhof P \& Strous GJ. Dimerization and signal transduction of the growth hormone receptor. Molecular Endocinology 200317 967-975.

7 Brown RJ, Adams JJ, Pelekanos RA, Wan Y, McKinstry WJ, Palethorpe K, Seeber RM, Monks TA, Eidne KA, Parker MW \& Waters MJ. Model for growth hormone receptor activation based on subunit rotation within a receptor dimer. Nature Structural and Molecular Biology 200512 814-821.

8 Argetsinger LS, Campbell GS, Yang X, Witthuhn BA, Silvennoinen O, Ihle JN \& Carter-Su C. Identification of JAK2 as a growth hormone receptor-associated tyrosine kinase. Cell 1993 74 237-244.

9 Argetsinger LS, Campbell GS, Yang X, Witthuhn BA, Silvennoinen O, Ihle JN \& Carter-Su C. Mechanism of signaling by growth hormone receptor. Physiological Reviews $1996 \mathbf{7 6} 1089-1107$.

10 Herrington J \& Carter-Su C. Signaling pathways activated by the growth hormone receptor. Trends in Endocrinology and Metabolism $200112252-257$.

11 Takahashi K, Kaji H, Okimura Y, Goji K, Abe H \& Chihara K. Brief report: short stature caused by a mutant growth hormone. New England Journal of Medicine 1996334 432-436.

12 Chihara K, Takahashi K, Kaji H, Goji K, Okimura Y \& Abe H. Short stature caused by natural growth hormone antagonist. Hormone Research 199849 41-45. 
13 Deladoey J, Gex G, Vuissoz JM, Strasburger CJ, Wajnrajch MP \& Mullis PE. Effect of different growth hormone (GH) mutants on the regulation of GH-receptor gene transcription in a human hepatoma cell line. European Journal of Endocrinology 2002146 573-581.

14 Petkovic V, Besson A, Thevis M, Lochmatter D, Eblé A, Flück CE \& Mullis PE 2007 Evaluation of the biological activity of a GH mutant (R77C) and its impact on $\mathrm{GH}$ responsiveness and stature. Journal of Clinical Endocrinology and Metabolism (Epub).

15 Prader A, Largo RH, Molinari L \& Issler C. Physical growth of Swiss children from birth to 20 years of age. Helvetica Paediatrica Acta 198952 1-125.

16 Brook CG. Growth Assessment in Childhood and Adolescence. Oxford: Blackwell, 1982.

17 Ranke MB. Diagnosis of growth hormone deficiency and growth hormone stimulation tests. In Diagnosis of Endocrine Function in Children and Adolescents, pp 107-128. Base: Krager, 2003

18 Tsvetnitsky V, Auchi L, Nicolaou A \& Gibbons WA. Characterization of phospholipid methylation in rat brain myelin. Biochemical Journal $1995 \mathbf{3 7 0} 239-244$.

19 Deladoëy J, Stocker P \& Mullis PE. Autosomal dominant GH deficiency due to an Arg183His GH-1 gene mutation: clinical and molecular evidence of impaired regulated GH secretion. Journal of Clinical Endocrinology and Metabolism. 200186 3941-3947.

20 Besson A, Salemi S, Deladoey J, Vuissoz JM, Eble A, Bidlingmaier M, Burgi S, Honegger U, Fluck C \& Mullis PE. Short stature caused by a biologically inactive mutant growth hormone (GH-C53S). Journal of Clinical Endocrinology and Metabolism. 2005 90 2493-2499.

21 von Laue S, Finidori J, Maamra M, Shen XY, Justice S, Dobson PR \& Ross RJ. Stimulation of endogenous GH and interleukin-6 receptors selectively activates different Jaks and Stats, with a Stat5 specific synergistic effect of dexamethasone. Journal of Endocrinology $2000165301-311$.

22 Ross RJ, Esposito N, Shen XY, Von Laue S, Chew SL, Dobson PR, Postel-Vinay MC \& Finidori J. A short isoform of the human growth hormone receptor functions as a dominant negative inhibitor of the full-length receptor and generates large amounts of binding protein. Molecular Endocinology 199711 265-273.
23 Sotiropoulos A, Moutoussamy S, Renaudie F, Clauss M, Kayser C, Gouilleux F, Kelly PA \& Finidori J. Differential activation of Stat3 and Stat 5 by distinct regions of the growth hormone receptor. Molecular Endocinology 199610 998-1009.

24 Moutoussamy S, Kelly PA \& Finidori J. Growth-hormone-receptor and cytokine-receptor-family signaling. European Journal of Biochemistry 1998255 1-11.

25 Buckway CK, Guevara-Aguirre J, Pratt KL, Burren CP \& Rosenfeld RG. The IGF-I generation test revisited: a marker of GH sensitivity. Journal of Clinical Endocrinology and Metabolism. $2001865176-5183$.

26 Hamdan M, Bordini E, Galvani M \& Righetti PG. Protein alkylation by acrylamide, its N-substituted derivatives and cross-linkers and its relevance to proteomics: a matrix assisted laser desorption/ ionization-time of flight-mass spectrometry study. Electrophoresis 200122 1633-1644.

27 Ellgaard L \& Ruddock LW. The human protein disulphide isomerase family: substrate interactions and functional properties. EMBO Reports $2005628-32$.

28 Baneyx F \& Mujacic M. Recombinant protein folding and misfolding in Escherichia coli. Nature Biotechnolology 200422 1399-1408.

29 Codina A, Vilaseca M, Tarrago T, Fernandez I, Ludevid D \& Giralt E. Location of disulfide bonds in mature alpha-L-fucosidase from pea. Journal of Peptide Science 20017 305-315.

30 Kamikubo Y, Okumura Y \& Loskutoff DJ. Identification of the disulfide bonds in the recombinant somatomedin $\mathrm{B}$ domain of human vitronectin. Journal of Biological Chemistry 2002277 27109-27119.

31 Baumann G, Amburn K \& Shaw MA. The circulating growth hormone (GH)-binding protein complex: a major constituent of plasma GH in man. Endocrinology 1988122 976-984.

32 Baumann G, Vance ML, Shaw MA \& Thorner MO. Plasma transport of human growth hormone in vivo. Journal of Clinical Endocrinology and Metabolism. 199071 470-473.

Received 22 May 2007

Accepted 17 July 2007 